\title{
Chemokine (C-X-C Motif) Ligand 1 Measurement
}

National Cancer Institute

\section{Source}

National Cancer Institute. Chemokine (C-X-C Motif) Ligand 1 Measurement. NCI

Thesaurus. Code C128952.

The determination of the amount of chemokine (C-X-C motif) ligand 1 present in a sample. 